\title{
Thomas Fuller, Peter Heylyn and the English Reformation
}

\author{
JOHN DRABBLE
}

For generations, historians visited the site of the English Reformation in the manner of modern tourists who are attracted to a national shrine. For guide books, they had the older records and histories, while the forces of the contemporary world and their personal concerns arranged the highlights of the trip. In this way, the past and the present came together in the works of two seventeenth-century historians, Thomas Fuller, for whom the sixteenth century formed only a part of his larger Church History, ${ }^{1}$ and Peter Heylyn, who returned to the Reformation on more than one occasion and whose Ecclesia Restaurata was the first history devoted solely to that epoch. ${ }^{2}$ Born at the beginning of a new century, Heylyn in 1600 and Fuller in 1608, the two men grew to early manhood at a time when the English Church faced demands for change from Puritans who wanted its reformation along scriptural lines and Anglo-Catholics who would have it conform to the teachings and practices of the Visible Church. By the 1630's, when both men entered upon their life-long careers, a triumphant High Church party under William Laud had assumed control over the hierarchy. Thereafter, the Puritan and Laudian bodies in the Anglican cosmos fell toward one another in ever accelerating fashion. With their collision in 1642, the character of the older universe was forever altered, but so too were the images of the Reformation which Thomas Fuller and Peter Heylyn would subsequently create.

Fuller's family history joined easily with the dominant Anglicanism of Jacobean England. ${ }^{3}$ His father, an ordained minister, had been educated in those centres of Cambridge Puritanism, Trinity and St. John's. ${ }^{4}$ One uncle, Robert Townsend, had been an "excellent preacher," a chaplain to James I, Dean of Westminster, and, for fourteen months before his death in 1620, Bishop of Salisbury..$^{5}$ More important in Fuller's life was another uncle, John Devenant. A learned divine, Devenant was known for his Calvinist leanings in St. John's where he attained the mastership in 1614 through the efforts of the Puritan 
John Preston and where, if we accept the testimony of Simond D'Ewes, he continued to confute High Church doctrines as Lady Margaret Professor of theology. ${ }^{6}$ Under royal instructions to defend a moderate Calvinist position, he was appointed as one of four English delegates to the Council of Dort in 1619, and, upon the death of Townsend, he succeeded to the Bishopric of Salisbury where his staunch Protestantism remained a Calvinist beacon until his death in $1641 .^{7}$ Through Devenant's efforts, Fuller entered Queen's College in 1621 and, eight years later, Sidney Sussex College where the master was Samuel Ward, an old friend of the bishop, a moderate Calvinist, and, according to Fuller, "a true Protestant at all times." 8 By the 1630's, Devenant had also secured his nephew's first three positions in the Church, including the stall of Netherbury-in-Ecclesia, Beaminster, Dorsetshire, which Fuller called "one of the best prebends in England." mature Fuller moved his career in new directions as he published his first prose work, The Holy War, and emerged as a popular preacher in London. ${ }^{10}$ By 1641 , the values of a lifetime were also prepared to confront the events of his age. Fourteen years later, the same values and events continued to influence his image of the English Reformation.

For example, he never forgot how the reputation of the Reformation bishops had been stained by their Puritan attackers in 1641. On that occasion, the "root and branch" radicals had expanded their campaign against the Laudian bishops into a larger offensive against episcopacy itself. To defend the polity of the Church, Anglican moderates denied that all bishops were evil and, for their examples, pointed to the martyred bishops, Cranmer, Ridley, and Latimer. In response, the radical reply not only denied the martyrdom of the Reformation bishops but held them responsible for the failures of the Reformation. ${ }^{11}$ In such a manner, politics had created a new past as the heroes of Foxe became "Deformers rather than Reformers of our Religion," according to Smectymnuus, "halting and time-serving prelates," the "common stales" of the secular powers in John Milton's first anti-prelatical pamphlet. ${ }^{12}$

The attack violated Fuller's deepest sentiments; for, since childhood, he had been "possessed with a reverend esteem" for the martyred bishops, "which opinion having from my Parents taken quiet possession of my soul, they must be very forcible reasons which eject it."13 Thus, we can see why the impression made by the hyperbole of the Puritans had not left him when, in the Church History, he complained of "zealots" who "see faults of the Reformers, but not the difficulties of the Reformation." Constructing a past which replied to the Puritans of his day, Fuller argued that the true obstacles to reform were a numerous, intelligent, and powerful Catholic clergy that opposed such change and 


\section{0 / Renaissance and Reformation}

a laity which "being nustled in ignorance and superstition, could not on a sudden endure the extremity of an absolute Reformation."14

For the malice which William Prynne had heaped on the memory of Thomas Cranmer in 1641, Fuller reserved a special answer. Borrowing from old Roman Catholic charges, Prynne had reframed his material into a Puritan indictment of the first Anglican archbishop. ${ }^{15}$ Fourteen years later, "conceiving the protestants' cause much concerned therein," Fuller became an undisguised advocate who opened Cranmer's "just defense" with a plea that became a standard rhetorical device for future Anglican writers. Because a virtue is invariably accused by both extremes, he found that Cranmer "appears a worthy prelate, taxed by papists to be a heretic, by others (no papists) as guilty of superstition."16 So important was Cranmer's exoneration that after dealing with a few of the old Roman Catholic charges, the Church Historian proceeded to answer Prynne's accusations, including those that were "good only to swell the volume." 17 Thus, to the charge of the Catholic rebels of Lincolnshire that Cranmer and others had "subverted the faith of Christ," Fuller contemptuously reminded Prynne that "their pretended subverting of the faith was the reforming and confirming thereof." On the other hand, since the issue was Cranmer's virtue and not his sainthood, Fuller would not absolve his client's role in the condemnations of Lambert, Frith, and others. "This, indeed, cannot be denied. For though I am loath that Cranmer's head should. . . be plucked under water where he was innocent, I will leave him to sink or swim by himself where he was guilty..."

In defending the Reformation bishops on the basis of their moderation, Fuller held forth that quality which might have prevented the violence in his own world. He abhorred the "needless animosity" that surrounded such issues as the altar controversy of the 1630's and believed that "if moderate men had had the managing of these matters, the accommodation had been easy with a little condescension on both sides." 19 Moderate men, however, no longer controlled events. Gone were such High Church leaders as Lancelot Andrewes who, as Fuller observed, never forced a narrow conformity on others: "And it had not been amiss if such, who would be accounted his friends and admirers, had followed him in the footsteps of his moderation, content with the enjoying, without enjoining, their nrivate practices and opinions on others." ${ }^{20}$ On the Puritan side, such moderate divines as Richard Sibbes, "most eminent" for his "Christian humility," gave way to "ambitious clergymen" who, reversing "the silver trumpets of the sanctuary [and] putting the wrong end into their mouths, make what was appointed to sound Religion, to signify Rebellion." 21 As a result, the realm descended into a civil war which Fuller predicted would bring "ruin and desola- 
tion."22 He therefore used his London pulpit to urge a peaceful solution during the first year of warfare. On December 28, 1642, he echoed a proposal from the peace party in the Lords by calling for a national synod to solve the religious question. ${ }^{23}$ In March, 1643, he urged the sects to set forth their demands in a manner "most agreeable to Christian proceedings," rather than "with thundering and lightning of cannon, fire, and sword." 24 In the summer of 1643 , shortly before joining the king, he granted the need for a "Thorough Reformation," but insisted that it be "made with all due Christian moderation." 25

If, in 1643, such moderation meant that "the Supreme power alone hath a lawful calling to Reform a Church," by 1655, his Church History found that such deference toward "True Authority" justified the English Reformation. ${ }^{26}$ Thus, he discovered the elusive moderation not in his own world but in a created past where it was made to characterize and justify the actions of the Reformers. By necessity, the theme of moderation also served as an implicit criticism of the Puritan present. Whereas the Puritan would eliminate all signs of papistry, Fuller praised those Henrician reformers who "disclaimed only the ulcers and sores, not what was sound of the Roman Church. . "27 Puritanism had broken violently with the past; but the Church Historian admired the wisdom of those who, knowing that "New wine must be gently poured into old bottles," launched a moderate reformation in Edward's reign.

For as careful mothers and nurses, on condition to get their children to part with knives, are contented to let them play with rattles; so they permitted ignorant people still to retain some of their fond and foolish customs, that they might remove from them the most dangerous and destructive superstitions. ${ }^{28}$

And, against the narrow dogmatism of his age, Fuller held forth the comprehensiveness of the Thirty-Nine Articles which, by avoiding rigid definitions, allowed the church "to take in all, who differing in the branches, meet in the root of the same religion." 29

Molded in part by the present, the history drew upon a traditional Anglican historiography for much of its content. This is clear enough where Providence is made to guide each turning point of the English Reformation. It smiled upon Henry's fight with Rome, but frowned when the reformers bickered among themselves in Edward's reign. It strengthened the resolve of the Marian martyrs, hastened Mary's death, and paved the way for Elizabeth by first removing her enemies. ${ }^{30}$ In the manner of a preacher, Fuller often attached a religious truth to each Providential event. Thus, Wycliffe's success was attributed to "Divine Providence blessing the gospel, and to the nature of truth itself, which though for a time violently suppressed, will seasonably make its own 
and clear passage into the world." 31 On the other hand, Fuller was not surprised that God might guide the actions of an immoral king such as Henry VIII, "for it is usual with God's wisdom and goodness to suffer vice to sound the first alarm to that fight wherein virtue is to have the victory." 32

The work abounds in the lessons drawn from the pulpit. Some stand forth in larger relief as when Cardinal Wolsey assumed his familiar role as the great example of how "unlimited Power and Pride" can be humbled by God..$^{33}$ Others served to demonstrate a favorite Protestant theme. In this regard, the story of John Jewell's subscription to Roman Catholicism during Mary's reign showed how a fallen man might rise from sin. Finding no peace in his cowardice, Jewell fled to Frankfurt where a tearful congregation of exiles forgave and embraced a penitent sinner who had asked for their pardon. "Yea, whosoever seriously considereth the high parts Mr. Jewell had in himself, and the high opinion others had of him, will conclude his fall necessary for his humiliation." 34

This is the stuff of the pulpit, and, in telling his story, Fuller adopted the vibrant imagery and Biblical allusions which were the hallmarks of the Protestant ministry. So, for example, he ascended the pulpit to describe the persecutions which set in after the death of William Sawtrey. "So that now the ship of Christ tossed with the tempest of persecution, had all her sails taken down; yea, her mast cut close to the deck; and, without making any visible show, was fain to lie poor and private till this storm was overpassed." 35 For his text, Fuller had turned to John Foxe, an author whom he referred to as the "sole emperor" among the martyrologists. ${ }^{36}$ Like Foxe, the Church Historian edified his readers by giving a prominent place to the travails of the Christian martyrs. Thus, the survival of that "inconsiderable pittance of faithful professors," the pre-Reformation martyrs, offered "pregnant proof" that "God hath always been ambitious to preserve and prefer little things." 37 The Marian martyrs served even greater didactic ends; and having asked "What use to be made of the Martyrs' Sufferings?" - Fuller answered with an exhortation that God be glorified and praised, that the doctrine for which so many died be defended, and that the memories of such faithful witnesses be preserved from scandal. ${ }^{38}$

A different kind of Reformation history greeted Charles II in 1661, one that was indissolubly linked to the life and career of its author, Peter Heylyn. ${ }^{39}$ Nothing is known of the influences which bore on the author's early intellectual development, but attending Magdalen College, Oxford, when William Laud was President of St. John's, Heylyn was undoubtedly exposed to High Church ideals by the time he received his B.A. in 1617 and his M.A. in $1620 .^{40}$ Thereafter, upon entering 
his studies for the priesthood, he "thought no course so proper and expedient" than to follow the instructions which James I had issued to the university in 1617; and, avoiding the fashionable Protestant abridgements, he concentrated on the "Fathers and Councils, Schoolmen, Histories, and Controversies." 41 The effect of his studies was obvious enough when, in 1627, he maintained the visibility of the Church against Oxford's leading Calvinist and Regius Professor of Divinity, John Prideaux. ${ }^{42}$

The disputation with Prideaux brought Heylyn to the attention of William Laud, who had debated the same issue with George Abbot in $1603 .{ }^{43}$ By the 1630's, the combative talents of the younger man were put to use in pursuing the Feofees of Impropriations who threatened the Laudian campaign for conformity; ${ }^{44}$ John Prideaux, a Calvinist thorn in the university over which Laud was Chancellor,45 William Prynne, the archbishop's most bitter Presbyterian enemy; ${ }^{46}$ and John Williams, Bishop of Lincoln and Laud's oldest enemy in the hierarchy. ${ }^{47}$ By 1636, Heylyn also had discovered how history could serve his party's interests. When the king called upon him to oppose a rising sabbatarianism, Heylyn dutifully found that it "neither hath the doctrine of Scripture to authorize, or the practice of the Church of God... to confirm and countenance it." 48 In the same year, two historical briefs on the altar controversy enabled him to renew his attack on Bishop Williams. $^{49}$ In the midst of these activities and having "received all imaginable encouragements" from Laud, Heylyn commenced his Ecclesia Restaurata in $1638 .^{50}$ This latest endeavour was interrupted by the collapse of the Carolingian regime and the start of the civil war, but Heylyn soon found new political uses for history. In the Convocation of 1640, he discovered an Elizabethan precedent which allowed the clergy to vote a benevolence to the crown after Parliament was dissolved; he defended in committee the seventh canon "conceiving some Rites and Ceremonies"; and he compiled those articles of enquiry which the ninth canon ordered established for all church visitations. ${ }^{51}$ Early in 1641 , when the House of Lords voted that no bishop should sit in judgement of the Earl of Strafford, Heylyn defended the right of the prelates to participate in all matters brought before the upper house in his $D e$ Jure Paritatis Episcoporum. ${ }^{52}$ One year later, he entered the fray against the Smectymnuans with a history of episcopacy, because, as he later explained, "having found good success in that kind before," such a work could not "but be of special use and efficacy." 53

Similar thoughts regarding the usefulness of history were still in mind in 1661 when, in the manner of so many historians before him, Heylyn dedicated his Ecclesia Restaurata to the reigning monarch. ${ }^{54}$ But whereas an historian such as John Foxe had offered only a veiled suggestion 
that Elizabeth I might benefit from the lessons of history, Heylyn served immediate notice that his work was designed to instruct Charles II.

It is, (dread sir), an History of the Reformation of the Church of England ....A piece not to be dedicated to any other, than your sacred Majesty; who, being raised by God, to be a nursing father to this part of his Church, may possibly discharge that duty with the greater tenderness, when you shall find upon what rules of piety and Christian prudence the work was carried on by the first reformers. Which being once found, it will be no hard matter to determine of such means and counsels whereby the Church may be restored to her peace and purity; from which she is most miserably fallen by our late distractions.

With Heylyn's help, Charles II would learn that "some tares grew up almost immediately with the wheat itself; because, from the beginning of the Reformation, the "Lord's good seed" was mixed with the "fruits of error and false doctrine, of faction, schism, disorder, and perhaps sedition." 55 In short, the English Reformation would be viewed through the ring of the archbishop whose memory Heylyn would also preserve in his Cyprianus Anglicus.

By imposing the same narrow orthodoxy on the past which Laudians demanded in the present, the Ecclesia Restaurata inevitably showed a special hostility towards sixteenth-century Nonconformity. In this regard, Heylyn echoed the sentiments and, on occasion, even the words of his episcopal patron. Convinced that foreign congregations of his day were "nests and occasions of schism," Laud believed "that it were better there were no Foreign Churches nor strangers in England." 56 Extending this attitude into the past, Heylyn bemoaned the invitation which had allowed John a Lasco's congregation to settle in the London of Edward VI, because it "proved the occasion of no small disturbance to the proceedings of the Crown, and the quiet ordering of the State." 57 And, as Laud had warned that the foreign temples "which are now a Church within a Church, will in time grow to be a kind of another commonwealth within this," so Heylyn concluded that a Lasco's privileges "proved in effect the setting of one Altar against another in the midst of the Church, and the erecting of a commonwealth in the Kingdom." 58

If the bane of High Churchmen was the Puritans, Heylyn's historical bete noire was John Calvin. Indeed, between the two, Heylyn saw no difference. To the Laudian charge which had blamed "all rebellious and disobedient intractableness in Parliament" upon the Puritans, Heylyn added the historical complement in a war-time tract entitled "The Stumbling Block of Disobedience and Rebellion Cunningly laid by Calvin." 59 A posthumous work, the Aerius Redivus, went even further by arguing that the Genevan discipline "was resolved to depose Kings, 
ruine Kingdoms, and subvert the Fundamental orders of all Civil States." 60 In a similar fashion, as Laudians held Puritanism responsible for "all schism and sauciness in the country, nay in the Church itself," 61 so the Ecclesia Restaurate found that Calvin's meddling in the affairs of the English Church produced similar results; for, "to have this Church depend upon his Direction," the Genevan reformer not only criticised Anglican ceremonies and vestments but forced his letters on the English authorities and "had his Agents in the Court, the Country, and the Universities." 62

Obviously, Heylyn was a narrow ideologue who appraised all men, past or present, by Laudian standards. How different was the approach of Thomas Fuller, who, judging all men by their "piety, painfulness, learning, and patience," avoided the more pejorative term "Puritan" and divided Nonconformists into the "mild and mannered," the "fierce and fiery." ${ }^{63}$ Such different standards were bound to separate the two men in both life and literature. How Heylyn must have winced to read in Fuller's history that "discreet and devout men were. . . doleful at the ruine of so pious a project" as that which was sponsored by the Feofees of Impropriations. ${ }^{64}$ Knowing that John Prideaux and John Williams were among those chosen for the episcopacy in 1641, imagine Heylyn's chagrin upon reading in the Church History that "his Majesty was careful to choose [the new bishops] out of the most sound for judgment and blameless for conversation." ${ }^{65}$ In turning to the past, Fuller could see the light of the Reformation first dawning with Wycliffe, but Heylyn could observe only the heterodoxies of the reformer and the sedition of his followers. ${ }^{66}$ If Heylyn could complain that the exiles who settled in Frankfurt were not saints but schismatics, Fuller could reply that " 'Schismaticks,' in my mind, is too harsh for such who fled for their conscience." 67

In Heylyn's mind, Fuller was too soft on the Puritan party, its fellowtravellers and its ultra-Protestant ancestors. Since the Church History gave aid and comfort to the enemies of Laudianism, it must be attacked along with them. Therefore, as Laudians had turned the term "Puritan" into a catchword to discredit their Carolingian opponents, Heylyn used the same tactic to find "a continuous vein of puritanism, such dangerous grounds for inconformity and sedition to be raised upon," in the Church History. ${ }^{68}$ How ironic, some might say "prophetic," since Fuller had refused to use the word "Puritan" because "profane mouths" had often used it "to abuse pious people." 69

But, within the Protestant tradition, Fuller was small game when we consider Heylyn's discussion of the Marian persecutions. Foxe had placed the blame for the conflagration on Queen Mary, because she had ; iven over "the execution of her power" to the clergy, thereby abusing 
her throne "to the destruction of Christ's church and people." 70 Out of deference to monarchy, some historians preferred to emphasize the clergy's role in the holocaust, especially when Foxe had provided so much evidence of their cruelty. "And surely so well inclined was Mary to her selfe," wrote John Speed, "that had not the zeale of her religion, and the authority of Churchmen over-swaied her own disposition, the flames of their consuming fires had not mounted so high." 71 For Thomas Fuller, however, new uses for the older story were provided by the activities of the sects during the 1640's. In 1646, he had warned his congregation that sectarian presumptuousness would bring God's wrath upon the nation:

When children begin to try Conclusions with a Candle, sporting themselves at in and out with it, their Parent use to take it from them, leaving them to doe pennance in the Darke for their Wantonesse. I am afraid that God will serve us in like manner: so many have dallied with the Scripture, producing it for the maintenance of their upstart, monstrous opinions. ${ }^{72}$

When blended with the didactic imagery found in his sermons, the experiences of the present gave Fuller new insights into the past; and, in his Church History, he observed that on Mary's accession, disputes over the liturgy had grown worse among the Protestants until "Providence put a period for a time to that controversy in England... Thus, when children fall out and fight about the candle, the parents, coming in and taking it away leave them to decide the differences in the dark." 73

But Heylyn's absorption with the disruptive forces of the Protestant left imposed itself on his history in even a more startling manner. The "Zwinglian Gospellers," he wrote, had created a series of disorders from the beginning of Mary's reign. They "raised up their Elizabeth Crofts whom they called the Spirit in the Wall to draw aside the people from their due allegiance," they made sport of Mary's supposed pregnancy, and they offered up prayers for her death. ${ }^{74}$ "Such," he deemed, "were the madnesses of these People," and such actions, along with Wyatt's Rebellion, he saw as the "Provocations" which led an exasperated government to revive the old laws against heresy. ${ }^{75}$ In effect, Heylyn became the first Anglican historian to discover that Tudor Protestants had helped to light the Marian fires; and, in the process, he became the first to leave unmentioned the religious reasons which led the government to begin the persecution. In this instance, the historian who had served as an enforcer of Laudian authority showed how easily his current attitudes could be substituted for the historical facts.

In another area of Laudian concern, Heylyn's history gave considerable attention to the physical losses incurred by the Church during the Reformation. That the crown and aristocracy had been the beneficiaries 
of that loss was no secret, but few Anglican historians had described the seamier side of the story except in so far as it related to the destruction of the monasteries. Even then, such facts had seldom been accompanied by critical commentary. John Stow, for example, had provided facts regarding some secular lands in his Survey of London, but he was more concerned with "the decay of worthy traditions" than with criticising "materialistic greed." 76 Not until the seventeenth century, when the tri-part alliance of king, church, and aristocracy began to break-up and the economic problems of the Church worsened, would Anglican historians begin to criticise the rape of the Ecclesia. Henry Spelman's Non Temerandis Ecclesiis called for a restitution of tithes and impropriations to the Church, but otherwise it said nothing about the nonmonastic property of the Church. ${ }^{77}$ Bishop Godwin, however, spoke for many in the hierarchy when he complained of the "hungary courtiers" in the reign of Edward VI whose "zealous intent to Prey" was not diverted by "the horridness" of the Church's "Sacred skeleton"78 John Haywood, who also knew the royal court of the 1630's, added to Godwin's indictment when he trenchantly remarked that the sale of the chantry lands and the enquiries into the Church's goods "enriched many, and ennobled some" during Edward's reign. ${ }^{79}$

Peter Heylyn, however, was especially suited to provide the most comprehensive statement on the plundering of the Ecclesia. He had observed how Laud's attempt to win back the patrimony of the Church had aroused the hostility of the laity. Such selfishness, as a Laudian would deem it, left Heylyn with few illusions regarding the motives of any aristocracy, past or present. In 1661, the Anglican temple was not only restored, but a penitent aristocracy was by then more aware of its political and social worth. The time had come for a High Churchman to tell another story about the English Reformation.

Yet Heylyn did not begin with the dissolution of the monasteries, although Speed, Spelman, and Dodsworth had testified to an Anglican interest in the matter. ${ }^{80}$ Even Thomas Fuller, no friend of the monks, had devoted an entire book to the history of the monasteries, and his summary of the consequences of the dissolution would be repeated by various authorities down to our century. ${ }^{81}$ Compared to Heylyn, however, no historian gives such little attention to the most revolutionary event in Henry's reign, nor is any High Church authority so coldly unsympathetic towards its results. In this respect, Heylyn remains the "bishop's darling," because he saw that as dependants of the Pope, the monasteries were beyond episcopal control and therefore mere "excrescences upon the body of the Church." ${ }^{2}$ While High Church historians will come to regard the dissolution of the monasteries as the greatest blow against the Church's temporal estate, Heylyn preferred to 
recall that from the monastic lands, Henry created six new episcopal sees, established cathedral churches which had supported monks or canons into sees with secular priests, placed public readers in the universities, and attached a school to every cathedral. Perhaps only a Laudian scholar could therefore find that in its "Polity and endowments," Henry VIII "had left the Church in many respects, in better condition than he found it. ..." 83

For Heylyn, the more important spoliation took place in the reign of Edward VI when the "Grandees of the Court" began a reformation for selfish reasons and were followed by members of Parliament "who were to make or improve their estate," landlords who secured the profits of patronage, and aristocrats who pretended a zeal for a more simple religion in order to strip the Church of its liquid wealth. ${ }^{84}$ Nor did Heylyn doubt that the aristocracy again benefitted during Elizabeth's reign when the further destruction of episcopal lands was carried out by an array of policies that included the maintenance of vacant sees "until the whole garden of the Church had been culled out of it," the granting of long leases to court favourites, the forced exchanges of lands with the crown, and the placing of courtiers in the administrative positions of the Church. ${ }^{85}$ His indictment of the Reformation laity, the most elaborate to date from an Anglican, contained profound implications for the reputation of two monarchs who had failed to protect their ecclesiastical inheritance. For Edward alone, however, was an historiographical tradition reversed. Foxe had likened the boy king to Josiah, Fuller had devoted many pages to extolling his virtues, and even Heylyn found Edward to be "a most Pious and Religious Prince" when a rhetorical need so demanded. ${ }^{86}$ But in matters relating to the destruction of the church's wealth, the Laudian scholar could not find Edward's death "an infelicity to the Church of England," for had he lived longer, "the poor Church" would have been left as naked as an infant. ${ }^{87}$ Although the Church continued to suffer similar losses under Elizabeth, Heylyn rendered no harsh judgements against the Virgin Queen whose reign still symbolized a golden age, whose name was still beyond reproach, and whose Church was the supposed model for Laud's conformity drives in the 1630's.

The last area of Laudian concern which occupied Heylyn's historical efforts stemmed from his party's insistence that the Anglican Church be restored to its spiritual independence. Towards that end, he had made a lasting contribution in a polemical pamphlet of 1645 wherein he argued "that nothing was done in the Reformation, but what was acted by the clergy in their Convocation, or grounded on some Act of theirs precedent to it, with the Advice, Counsel, and Consent of the Bishops and other Learned men assembled by the King's Appointment." 88 The argument 
was Heylyn's direct response to the recent actions of the Long Parliament. In December, 1640, its angry resolutions had asserted the primacy of the legislature in religious matters. In 1643, Parliament abolished episcopacy in a de facto, if not legal sense; called a Puritan dominated Assembly of Divines to Westminster; adopted the Solemn League and Covenant; and attacked the ceremonies of the Church. Two years later, the legislature sent Laud to his death, published a Directory of Worship, and made further moves towards Presbyterianism.

In this context, Heylyn had taken his 1645 excursion to the site of the English Reformation where he discovered that the jurisdictional revolution which culminated in the Act of Supremacy had begun when the clergy, by its submission in 1531, recognized the King's limited headship. Indeed, he held that the Act of Supremacy was "made. . . only for corroboration and confirmation of that which had been done in the Convocation," an assertion which clearly distorted the words of the statute. ${ }^{89}$ Furthermore, he insisted that because the clergy had submitted themselves directly to the king in 1531 , the statute which confirmed the same in 1534 "neither brought the Convocation under the command of Parliament, nor rendered them obnoxious to the power thereof." 90 Instead, both Parliament and Convocation henceforth existed as parallel and equal bodies under the crown. For proof, he turned to the English Reformation where he found that "the Parliament did nothing in it but that sometimes upon the Post-fact it was thought fit to add some strength to the Decrees and Determinations of the Church (especially in inflicting punishments on the Disobedient) by Civil Sanctions." 91

How different was the position of Thomas Fuller, who, finding a middle ground between the two parties, told his readers that Henry VIII resolved upon a Reformation "by the advice and consent of the clergy in Convocation and great council in Parliament." 92 Fuller believed that in religious matters, Convocation retained the right to be consulted and to determine orthodox doctrine. But, because church law had always been subject to "secular laws and national customs," Parliament reserved for itself "the confirming power of all canons ecclesiastical" whenever the liberty or property of the subject was affected.$^{93}$ No less than the Laudians before him, however, Heylyn still found such views not only "false," but "contrary to the power and practice" of the Visible Church and "dangerous" to the authority of Convocation. ${ }^{94}$

To be sure, whether in the Articles of 1536 or the Institutes of a Christian Man of 1637, there were instances when doctrinal statements proceeded solely from Convocation. ${ }^{95}$ But the overall argument required the skills of a rhetorician, because all too frequently the evidence for its proof was insufficient or damaging. How, for example, could the part which Parliament had played in the formulation of the Six Articles be 
disregarded except by the most forceful pleading, which, having attempted in the Ecclesia Vindicata, he wisely avoided in the larger history. ${ }^{96}$ Even more difficult problems were posed by the Acts of Uniformity of 1552 and 1559. In the first, the authority of Parliament was said to have not only "set forth" the Prayer Book of 1549 but to have annexed the revised liturgy (or Second Prayer Book) to the act itself. ${ }^{97}$ In a similar manner, the Elizabethan uniformity act claimed a parliamentary authorization for the Prayer Books of both 1553 and 1559.98 Disregarding both uniformity acts, Heylyn insisted that "the making of one uniform Order of celebrating divine Service was the work of the Clergy, the making of the Penalties was the work of the Parliament." 99 By emphasizing the clerical authorship of the liturgy, he had diverted attention from the question of its parliamentary authorization, but even such a rhetorical sleight of hand could not erase the words by which Parliament had laid statutory claim to a portion of the spiritual jurisdiction.

Heylyn did not insist, as would future High Church historians, that the liturgical changes under Edward VI originated with Convocation. He was, however, the first historian to argue that the Forty-two Articles proceeded from that body alone. For his evidence, he referred to the title given the articles upon their publication, Articuli de quibus in (ultima) Synodo Londinensi, Anno 1552... ${ }^{100}$ Yet, he must have known that the matter was controversial even in his day. According to Foxe, Weston in the Convocation of 1553 and Cranmer in the Oxford disputation of 1554 had both denied the veracity of the title page. ${ }^{101}$ If he was unfamiliar with those embarrassing pages in Foxe, which is doubtful, he could not avoid the more destructive comments of Thomas Fuller. Having turned to the records of Convocation, the Church Historian announced that "they are but one degree above blanks" and, regarding the book wherein the articles were contained, concluded that "very few in the Convocation ever saw it, much less explicitly consented thereunto." 102

Heylyn was outraged..$^{103}$ No wonder, for he had once written that "If the Reformation be in points of doctrine," the matter "belongs only to the whole body of the clergy in their convocation rightly called and constituted." 104 But a convocation which Fuller called "barren" was an unlikely parent of doctrinal change and, consequently, a poor witness for the church's alleged supremacy. ${ }^{105}$ Heylyn was therefore forced to construct new supports for what, in fact, had become a High Church imperative. In doing so, he provided future members of his party with the foundations of an argument which depended as much on forceful pleading as on the presentation of any conclusive evidence.

First, he relied on a defence which John Philpot had provided the 
Forty-two Articles in the Convocation of 1553. Replying to Weston's objections, Philpot had asserted that since a former convocation had authorized a group of divines to make and set forth the document in question, the title page "might be well said to be done in the Synod of London." 106 Fuller, who had repeated the same story, wrote cautiously of such a transference of power, "I would be thankful to him who would produce the original instrument thereof." 107 Heylyn, however, pushed all doubt aside, placed the royal appointees on a "grand committee," and gave the lesser group full power to debate, conclude, and publish their findings in the name of the rest. ${ }^{108}$ Second, to the strength of a forceful language, he added the prestige of two monarchs. Since the Articles were ostensibly published under the authority of Edward VI, Heylyn argued that the synodical claims found in the title must be true, otherwise that "most Pious and Religious Prince must needs be looked on as a Wicked and most Lewd Imposteur, in putting such an horrible Cheat upon all His Subjects by Fathering these Articles on the Convocation which begat them not, nor ever gave consent to them." 109 In addition, the articles had been retained by Queen Elizabeth I until 1562, "which certainly She had not done, had they been commended to Her by a less Authority, than a Convocation." 110 In the midst of such monarchical endorsements, the rhetorical urge produced yet another suggestion which future High Churchmen would develop into an argument. "And yet it is not altogether improbable, but that these Articles being debated, and agreed upon, by the said Committee, might all pass the Vote of the whole Convocation, though we find nothing to that purpose in the Acts thereof."

What more could be expected from an historian who, to build a Laudian model of the past, discarded facts that did not easily join together and kept only those that might lie neatly on the cement of his arguments. If such techniques did not produce a stronger structure, they did yield one in which the clear lines of the Laudian school were revealed. But a history that responded so fully and partially to the questions of the day was likely to be judged by its ability to meet the existential requirements of its critics. Heylyn's work was especially liable to such judgements. Henry Hickman, for example, not only accused Heylyn of having "muddied the first Springs of the Reformation [with] the abhorred filth of covetousness," but asked, "Can the Conscience of a Protestant comfortably repose itself on such a foundation as you have laid?" 112 For Roman Catholic writers, Heylyn's History took on great polemical worth after a tract entitled "The Church of England According to Dr. Heylyn's History of the Reformation" was published, significantly enough, in the reign of James II. ${ }^{13}$ Thereafter, the Ecclesia Restaurata became a favorite source for the old religionists. 
Undoubtedly, Heylyn would have been pleased to learn that in matters relating to the role of Convocation, the origins of the Church's poverty under Edward VI, the place of Nonconformity within the Anglican tradition, his History, even in its rhetorical aspects, continued to serve a future High Church cause.

Fuller, on the other hand, succoured not a sect but an older Protestant tradition which, with the didacticisms and the stylistic devices of the pulpit, he reshaped into conformity with his deeply held moderation. The moderation which pervaded his work was, by his definition, a combination of discretion and charity. ${ }^{114}$ If the first gave him a greater sensitivity toward the political realities of his day, the second prevented him from measuring the quick and the dead by a common standard. History, for Thomas Fuller, served to heal and not to sharpen differences among his contemporaries. Above all, it was an eminently sensible presentation of the past which contained a number of intelligent observations about the English Reformation. Unfortunately, the author fell into disfavour after his death and, during the eighteenth century, his writings were decried or neglected. Some disliked his digressions or objected to his "merry jests" because they did not "become the gravity of a Church Historian." 115 More important, in an age that avoided his playful alliteration, his vibrant imagery, and his idiomatic vocabulary, Fuller's style became unfashionable. ${ }^{116}$ Gilbert Burnet undoubtedly spoke for many in the next generation when he observed that "being a man of fancy, and affecting an odd way of writing, his work gives no great satisfaction.'

Burnet's comments and his History of the English Reformation were themselves responses to the larger forces of a new age in which antiCatholic tensions were moving the nation toward the hysteria of the Popish Plot and the Exclusion Crisis. At home, the alarm caused by the impending Catholic Succession increased when, in 1676, a new translation of Nicholas Sender's Rise and Growth of the Anglican Schism appeared in Paris. To counter what was deemed the latest Catholic danger, "some persons of great worth and eminence" urged Burnet to issue a counterblast in which the story of the English Reformation would be set forth more clearly and fully than ever before. ${ }^{118}$ Chief among those who urged the task upon Burnet was William Lloyd, a Latitudinarian whose success with the new plain prose style championed by John Wilkins and John Tillotson made him, according to Burnet, "one of the greatest masters of style now living." 119 To help in the editing of the first part of Burnet's History, Lloyd would be joined by two other masters of the new style, Tillotson and Edward Stillingfleet. Style alone would not distinguish Burnet's History from those of the preceding generation. As a member of the Royal Society who had been taught his science by 
John Wilkins and Robert Boyle, Burnet wished to avoid the pitfalls of Heylyn, who had not only been "violently carried away by some particular conceits" but, equally unpardonable, had "never vouched any authority for what he writ. .." 120 To tell the entire story, Burnet set about gathering the original sources which would accompany his great work. Thus, with the deaths of Fuller and Heylyn, both an age and its way of writing history had ended. With Gilbert Burnet, a new age would usher in a new kind of Reformation history.

\section{William Paterson College}

\section{Notes}

1 Thomas Fuller, The Church History of Britain; from the Birth of Jesus Christ until the year 1648, ed. J.S. Brewer, 6 vols. (Oxford: University Press, 1845). The work was first published in 1655 .

2 Peter Heylyn, Ecclesia Restaurata; or, the History of the Reformation of the Church of England, ed. James Cragie Robertson, 2 vols. (Cambridge: University Press, 1849).

3 For the standard biography of Fuller, see John Eglington Bailey, The Life of Thomas Fuller (London: Basil Montagu, Pickering, 1874).

4 Bailey, pp. 18-20.

5 Thomas Fuller, The History of the Worthies of England (1840; rpt. New York: AMS Press Inc., 1965), I, 231-32.

6 Fuller, Worthies, III, 360; Irvonwy Morgan, Prince Charles's Puritan Chaplain (Ruskin House: George Allen \& Unwin Ltd., 1957), pp. 19-20; James Orchard Halliwell, ed., The Autobiography of Sir Simonds D'Ewes. . . . , London: Richard Bentley, 1845), I, 120.

7 Bailey, pp. 67-77; Fuller, Worthies, III, 360.

8 Fuller, Worthies, I, 488; Bailey, pp. 73-74, 101-06.

9 Thomas Fuller, Appeal of Injured Innocence unto the Religious, Learned, and Ingenuous Reader in The History of the University of Cambridge, and of Waltham Abbey, ed. James Nichols (London: Printed for Thomas Tegg, 1840), p. 286.

10 Bailey, pp. 173-81.

11 Samuel Rawlinson Gardiner, History of England. . . (1884; rpt. New York: AMS, 1965), IX, 274-87; 296-99; 378-83; 388-92; William Lamont, Marginal Prynne, 1600-1669 (London: Routledge \& Kegan, 1963), pp. 50-55.

12 Smectymnuus, An Answer to a Book Entitled, an Humble Remonstrance. . . . (1641), p. 11; John Milton, Of Reformation touching Church-Discipline in England, in Complete Prose Works of John Milton (New Haven: Yale University Press, 1953), I, 532-33.

13 Thomas Fuller, The Holy State and the Profane State, ed. Maximilian Graff Walten (New York: Columbia University Press, 1938), II, 291.

14 Fuller, Church History, III, 139.

15 William Prynne, The Antipathie of the English Lordly Prelacie.... (London, 1641), pp. 131-34.

16 Fuller, Church History, III, 67.

17 Fuller, Church History, III, 71.

18 Prynne, Antipathie, p. 132; Fuller, Church History, III, 70-71. 
19 Fuller, Church History, IV, 111-12.

20 Fuller, Church History, VI, 40.

21 Fuller, Worthies, II, 185; Church History, IV, 153.

22 Thomas Fuller, "A Fast Sermon Preached on Innocent's Day," in The Collected Sermons of Thomas Fuller, 1631-1659 (London: Gresham Press, 1891), I, 245.

23 Fuller, "A Fast Sermon," Sermons, I, 249-50.

24 Thomas Fuller, "A Sermon Preached at the Collegiate Church of St. Peter in Westminster," in Sermons, I, 283.

25 Fuller, "A Sermon of Reformation," Sermons, I, 302-03.

26 Fuller, "A Sermon of Reformation," Sermons, I, 303; Church History, IV, 92-93.

27 Fuller, Church History, III, 95.

28 Fuller, Church History, IV, 18, 20.

29 Fuller, Church History, IV, 318.

30 Fuller, Church History, III, 95; IV, 199-200, 203, 250.

31 Fuller, Church History, II, 316.

32 Fuller, Church History, III, 95.

33 Fuller, Church History, III, 23-28, 47-51.

34 Fuller, Church History, IV, 159.

35 Fuller, Church History, II, 396.

36 Fuller, Church History, IV, 179.

37 Fuller, Church History, III, 7-8.

38 Fuller, Church History, IV, 203.

39 There are three biographies of Heylyn. The first, by George Vernon, was attached to the Historical and Miscellaneous Tracts of Peter Heylyn (London: Printed for M. Clark, 1681). Dissatisfied with the editing of this life, Vernon subsequently published The Life of the Learned and reverend Dr. Peter Heylyn. . . . (London: Printed for C.H. and Sold by E. Vize, 1682). The preface of Vernon's biography offended John Bernard, Heylyn's son-in-law, who then wrote Theologo-Historicus, or the True Life of. . .Peter Heylyn (London: n.p., 1683). Robertson has attached Bernard's biography to the first volume of the Ecclesia Restaurata.

40 Bernard, xl-xli; Vernon, The Life, pp. 10-13.

41 Bernard, xiv-xlvi; Vernon, The Life, pp. 16-17. In Heylyn's view, James's order was "the first step toward suppressing that Reputation which Calvin and his Writings had attained unto in that University...." Peter Heylyn, Cyprianus Anglicus. ... (London: Printed by J.M. for A. Seile, 1671), p. 67.

42 Peter Heylyn, Examen Historicum: or a Discovery and Examination of the Mistakes, Falsities, and Defects in some Modern Histories.... (London: Printed for Henry Seile \& Richard Royston, 1659), II, 214-15; Bernard, xiv-xvii; Vernon, The Life, pp. 26-28.

43 Heylyn, Cyprianus Anglicus, pp. 49, 166-67.

44 Heylyn, Cyprianus Anglicus, pp. 198-200; Heylyn, Examen Historicum, I, 208-11; Bernard, xcii-xcv; Vernon, The Life, pp. 57-63.

45 In his second encounter with Prideaux, this time in 1633 during his examination for a doctorate in divinity, Heylyn antagonized the Regius Professor by defending another favourite High Church cause, viz. the authority of the Church to determine controversies of faith, interpret scriptures, and establish rites and ceremonies. For remarks made during the disputation, Prideaux had subsequently to defend himself before the Chancellor. Heylyn, however, denied that he had given information against Prideaux. Heylyn, Examen Historicum, II, 211-19; Robertson's notes in Bernard's. Theologo-Historicus, xcii-xcvi; Vernon, The Life, pp. 26-28. In the same year, Heylyn also translated a Latin lecture of 1622 in which Prideaux had taken a moderate stand on the Sabbath question, a position which now brought him into disrepute with many Puritans. Heylyn, Cyprianus Anglicus, p. 246.

46 In 1634, Heylyn extracted those passages from Prynne's Histriomastix which the government used in presenting its charge of sedition against the author. "For the reward of which 
and other good services that with wonderful prudence, as well as diligence, he faithfully performed; His Majesty was graciously pleased to requite him, by bestowing on him the parsonage of Houghton, in the Bishopric of Durham, worth near 400. per annum." Vernon, The Life, pp. 51-52. See also, Lamont, Marginal Prynne, pp. 28-33.

47 In 1635, Heylyn led the prebendaries of Westminster in bringing charges of embezzlement against Bishop Williams. Vernon, The Life, pp. 67-87; Bernard, xcix-ciii.

48 Peter Heylyn, The History of the Sabbath (London: n.p., 1636), in the Tracts, p. 497.

49 In 1627, Williams had taken a moderate stand on the altar question in a pamphlet addressed to the Vicar of Grantham. That pamphlet, reprinted in 1636, was answered by Heylyn's A Coal from the Altar (1636). When Williams responded in The Holy Table, Name and Thing (1636), Laud denounced the work from his seat on the Council and Heylyn answered it with Antidotum Lincolnesis (London: 1637). When Williams was suspended in 1637, Heylyn received the treasurership of Westminster Cathedral. Gardiner, VIII, 253-55.

50 Vernon, "The Life," in The Tracts, xiii.

51 Heylyn, Cyprianus Anglicus, 394-419; Vernon, The Life, pp. 98-100.

52 Peter Heylyn, De Jure Paritatis Episcoporum. . .in The Tracts, pp. 733-745.

53 Heylyn, "Preface to the Reader," Ecclesia Vindicata, in The Tracts, p. 184. Originally published under the pseudonym Theolophilus Churchman, The History of Episcopacy (London, 1642) subsequently formed Part II, sections v and vi, of the Ecclesia Vindicata (London, 1657). It appears in The Tracts on pp. 187-315.

54 Historians who had previously offered dedications to their monarchs included John Foxe (Acts, 1563), William Camden (Britannia, 5th ed., 1600 and 6th ed., 1607), Bishop Godwin (Annales, 1616 and the English translation of 1630), John Speed (History of Great Britain, 1611), and Lord Herbert (Henry VIII, 1645).

55 Heylyn, Ecclesia Restaurata, I, iii.

56 Heylyn, Cyprianus Anglicus, 262.

57 Heylyn, Ecclesia Restaurata, I, 189.

58 William Laud, The Works of... (Oxford: John Henry Parker, 1847-50), VI, Part 1, 26; Heylyn, Cyprianus Anglicus, II, 221; Ecclesia Restaurata, I, 189. Regarding the establishment of a French church in London during the reign of Elizabeth, Heylyn came to a similar conclusion: "Nor must we marvel if we find the like dangerous consequents to ensue upon it; for what else is the setting up of a presbytery in a Church founded and established by the rules of episcopacy, than the erecting of a commonwealth or popular estate in the midst of a monarchy." Ecclesia Restaurata, II, 337.

59 C.S.P.D., 1629-31, p. 411; Peter Heylyn, The Stumbling Block of Disobedience Cunningly laid by Calvin (London: Printed by E. Cotes for Henry Seile, 1658), in The Tracts, pp. 641-732.

60 Peter Heylyn, Aerius Redivivus; or, the History of the Presbyterians. . from the year 1536, to the year 1647 (Oxford, 1670), p. 11.

61 C.S.P.D., 1629-31, p. 411.

62 Heylyn, Ecclesia Restaurata, I, 134, 166-68, 192, 197, 201, 226-27.

63 Fuller, Church History, IV, 327-28; III, 496.

64 Fuller, Church History, VI, 87.

65 Fuller, Church History, VI, 236. Elsewhere, Fuller describes Prideaux as a forgiving man, "and though politicians will thence collect him no prudent man, Divines will conclude him a good christian." Worthies, I, 408.

66 Fuller, Church History, II, 316; Appeal, 435-438; Heylyn, Examen Historicum, I, 65-69.

67 Heylyn, Examen Historicum, I, 66-67; Fuller, Appeal, p. 494.

68 Perez Zagorin, The Court and the Country (New York: Atheneum, 1970), pp. 191-92; Heylyn, Examen Historicum, "Introduction to the Animadversions," n.p.

69 Fuller, Church History, IV, 327-28.

70 John Foxe, Acts and Monuments, ed. Stephen Reed Cattley (1837-39; 1841 rpt. New York: AMS, 1965), VIII, 624-28. 


\section{6 / Renaissance and Reformation}

71 John Speed, History of Great Britain. . . (London: n.p., 1611), p. 826. In this regard, Fuller followed Speed: "However, take queen Mary in herself, abstracted from her opinions, and by herself, secluded from her bloody counsellors, and her memory will justly come under commendation." Church History, IV, 247.

72 Thomas Fuller, "Fear of Losing the Old Light," Sermons, I. 455.

73 Fuller, Church History, IV, 123.

74 Heylyn, Ecclesia Restaurata, II, 145. John Stow had drawn attention to the first two episodes, although he did not lay the blame for them on the Zwinglians. John Stow, The Chronicles of England. . (London: R. Newberie, 1580), pp. 1068, 1078-82. Burnet found no evidence of Zwinglian complicity and, in an obvious reference to Heylyn, attributed the charge to "the malignity of one of our historians. ..." Gilbert Burnet, History of the Reformation of the Church of England (ed. Nicholas Pocock (Oxford: at the Clarendon Press, 1865), II, 439.

75 Heylyn, Ecclesia Restaurata, II, 149.

76 F. Smith Fussner, The Historical Revolution: English Historical Writing, 1580-1640 (New York: Columbia University Press, 1962), p. 219.

77 Henry Spelman, De Non Temerandis Ecclesiis; A Tract of the Rights and Respect due unto Churches (London: n.p., 1613)

78 Francis Godwin, Annales of England, Containing the Reign of Henry the Eighth, Edward the Sixth, Queen Mary. (London: Printed by A. Islip and W. Stansby, 1630), p. 224. Godwin was thankful "that these Locusts have not quite devoured the maintenance of the Laborers in this English Vineyard."

79 John Haywood, The Life and Raigne of King Edward the Sixth with the beginning of the Raigne of Queen Elizabeth (London: Printed for John Partridge, 1636), pp. 111-12, 372-74.

80 Speed had published a catalogue of the abbeys dissolved by Henry VIII in his History of Great Britain (London: n.p., 1611), pp. 787-802; Spelman's Non Temerandis had attached the sin of sacrilege to the dissolution; and, in 1655, the first volume of the Monasticon by Roger Dodsworth was published.

81 Fuller, Church History, III, Bk. Six. pp. 241-556.

82 Heylyn, Ecclesia Restaurata, I, 37. Smectymnuus had referred to Heylyn as Bishop Hall's "owne darling." An Answer to. . an Humble Remonstrance pp. 16-17.

83 Heylyn, Ecclesia Restaurata, I, 37.

84 Heylyn, Ecclesia Restaurata, I, 36, 97, 126-27, 201-02, 282-86. For more material, see also, I, 211-16.

85 Heylyn, Ecclesia Restaurata, I, 307-08, 347, 387-88. See also, I, 287-291.

86 Foxe, Acts, V, 698-99; Speed, History, p. 804; Fuller, Church History, IV, 110-120; Heylyn, Ecclesia Restaurata, I, 258. For Heylyn's remarks, see above p. 181.

87 Heylyn, Ecclesia Restaurata, I, ix. Elsewhere in the History, Heylyn left it for the reader to decide whether or not Edward, by his sixteenth year, "seemed to be worse principled in matters which concerned the Church." I, 282.

88 Peter Heylyn, Ecclesia Vindicata, "Dedication to the Reader," in The Tracts, n.p. The tract, which forms the first essay in the Ecclesia Vindicata, was originally entitled Parliaments Power, in lawes for Religion. . .(Oxford: Printed by Henry Hall, 1645).

89 Heylyn, The Tracts, p. 6. Instead, the Act of Supremacy says that "the King's Majesty justly and rightfully is and oweth to be the supreme head of the Church of England, and so is recognized by the clergy of this realm in their Convocations; yet nevertheless for corroboration and confirmation thereof, ... .Be it enacted by authority of this present Parliament that the King our sovereign lord. . shall be taken, accepted and reputed the only supreme head in earth of the Church of England. . .," 26 Henry VIII, cap. 1. in Henry Gee, Documents Illustrative of English Church History (London: Macmillan and Co., 1910), pp. 243-44.

90 Heylyn, The Tracts, pp. 4-5.

91 Heylyn, Ecclesia Vindicata, 'Dedication to the Reader,' The Tracts, n.p. 
92 Fuller, Church History, III, 93.

93 Fuller, Church History, II, 60-61; III, 105; Appeal, pp. 420, 473.

94 Heylyn, Examen Historicum, I, 52; see also, I, 100-03.

95 Heylyn, The Tracts, pp. 548-49; Ecclesia Restaurata, I, 10, 18, 39-40.

96 Heylyn had argued that Parliament in passing the Six Articles merely enforced existing doctrine and did not establish new articles of faith. Furthermore, he insisted, the matter was first discussed in Convocation before it came to Parliament. In fact, the records of Convocation and the Lords' Journals proved otherwise. He did not strengthen his case by admitting that Henry "did make use of his court of Parliament for the establishing and confirming of some points of Popery, which seemed in danger of a Reformation."In effect, "the Parliaments of those times did rather hinder and retard the work of Reformation." The Tracts, p. 11.

975 \& 6 Edward VI, Cap. 1. in Gee, p. 369.

981 Elizabeth, Cap. 2. in Gee, pp. 458-67

99 Heylyn, The Tracts, pp. 15-16.

100 Heylyn, The Tracts, p. 40; Examen Historicum, I, 122; Ecclesia Restaurata, I, 258-59; Cyprianus Anglicus, p. 307

101 Foxe, Acts, VI, 396, 468.

102 Fuller, Church History, IV, 109-10

103 Heylyn, Examen Historicum, I, 121-23. Fuller, however, held to his ground: "The Journals of the Convocation in this King's reign. . .are no better than blank paper. . .without any matter of moment (yea, any matter at all) registered to be performed by them." Appeal, p. 491.

104 Heylyn, The Tracts, p. 39; Cyprianus Anglicus, p. 308.

105 Fuller, Church History, IV, 110.

106 Foxe, Acts, VI, 396.

107 Fuller, Church History, VI, 396.

108 Heylyn, Ecclesia Restaurata, I, 257. See also, Examen Historicum, I, 121-22; Historia Quinqu-Articularis. ..(London: n.p., 1660) in The Tracts, p. 552.

109 Heylyn, Ecclesia Restaurata, I, 258; Examen Historicum, I, 122; The Tracts, pp. 552-53.

110 Heylyn, Examen Historicum, I, 122; The Tracts, p. 553; Ecclesia Restaurata, I. 259.

111 Heylyn, Ecclesia Restaurata, I, 258-59. Yet, only recently, he had been more positive: "And yet one may conclude as strongly that my mother died Childless, because my Christening is not to be found in the Parish register, as that the Convocation of this year was barren, because the Acts and Articles of it were not entred in the Journal Book." Heylyn, Examen Historicum, I, 122; Historia Quinqu-Articularis in The Tracts, p. 553.

112 Henry Hickman, Plus Ultra or Englands Reformation, Needing to be Reformed. Being An Examination of Doctor Heylyn's History of the Reformation of the Church of England. (London: n.p., 1661), pp. 3, 11.

113 The Church of England truly Represented, According to Dr. Heylyn's History of the Reformation, In Justification of her Royal Highness the Late Dutchess of Yorks Paper (London: Printed for the Author and Sold by M. Turner, 1686).

114 Thomas Fuller, The Holy State and the Profane State, ed. Maximilian Graff Walten (New York: Columbia University Press, 1938), II, 205.

115 Heylyn, Examen Historicum, "Introduction to the Animadversions," n.p. Bishop Nicholson complained that a work "so interlaced with pun and quibble" seemed "designed to ridicule the annals of our Church into fable and romance." For Bishop Warburton, the Church Historian was "Fuller the Jester." Addison, pp. 182, 216.

116 "The history of the literary work and reputation of Thomas Fuller is a curious one." S.C. Roberts, Thomas Fuller, a Seventeenth-Century Worthy. A Ludwig Mond Lecture (Manchester University Press, 1953), p. 3. A successful author during his life, Fuller's work fell into oblivion after his death. Then, in the nineteenth century, he was re-discovered by 


\section{8 / Renaissance and Reformation}

Robert Southey, Charles Lamb, and Samuel Coleridge. Thereafter, his major works were reprinted as were many of his lesser pieces. In the twentieth century, Fuller's style has received a delightful analysis in William Addison's Worthy Dr. Fuller (New York: The Macmillan Company, 1951).

117 Burnet, History of the Reformation, I, 6.

118 Burnet, History of the Reformation, I, 7.

119 Barbara Shapiro, John Wilkins, 1614-1672 (Berkeley: University of California Press, 1969), pp. 73-80, 163-64; Burnet, History of the Reformation, I, 7.

120 Burnet, History of the Reformation, I, 6. 